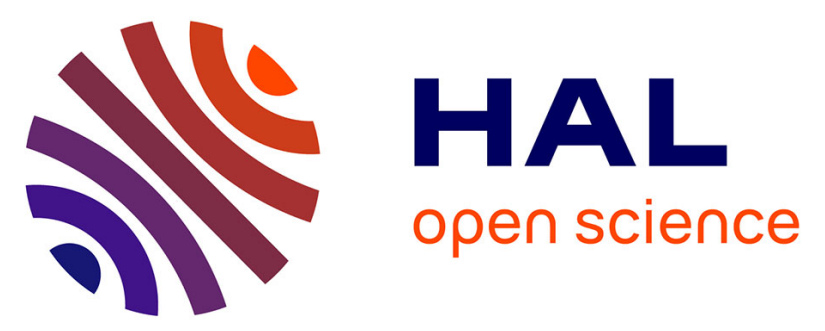

\title{
Development of a quantitative PCR-High Resolution Melting assay for absolute measurement of coral-Symbiodiniaceae associations and its application to investigating variability at three spatial scales
}

\author{
Anne-Leila Meistertzheim, Xavier Pochon, Susanna A Wood, Jean-François \\ Ghiglione, Laëtitia Hédouin
}

\section{To cite this version:}

Anne-Leila Meistertzheim, Xavier Pochon, Susanna A Wood, Jean-François Ghiglione, Laëtitia Hédouin. Development of a quantitative PCR-High Resolution Melting assay for absolute measurement of coral-Symbiodiniaceae associations and its application to investigating variability at three spatial scales. Marine Biology, 2019, 166 (2), 10.1007/s00227-018-3458-0 . hal-02297621

\section{HAL Id: hal-02297621 \\ https://hal.sorbonne-universite.fr/hal-02297621}

Submitted on 26 Sep 2019

HAL is a multi-disciplinary open access archive for the deposit and dissemination of scientific research documents, whether they are published or not. The documents may come from teaching and research institutions in France or abroad, or from public or private research centers.
L'archive ouverte pluridisciplinaire HAL, est destinée au dépôt et à la diffusion de documents scientifiques de niveau recherche, publiés ou non, émanant des établissements d'enseignement et de recherche français ou étrangers, des laboratoires publics ou privés. 
1 Development of a quantitative PCR-High Resolution Melting assay for absolute measurement of

2 coral-Symbiodiniaceae associations and its application to investigating variability at three spatial

3 scales

4

5

6

7

$8{ }^{1}$ Centre de Recherches Insulaires et Observatoire de l'Environnement, USR 3278 CNRS/EPHE/UPVD,

9 Laboratoire d'Excellence "CORAIL", Université de Perpignan, 66860 Perpignan Cedex, France

10 'Sorbonne Universités, CNRS, UPMC Univ Paris 06, UMR 7621, Laboratoire d'Océanographie Microbienne,

Anne-Leila Meistertzheim ${ }^{1,2 *}$, Xavier Pochon $^{3,4}$, Susanna A. Wood ${ }^{3}$, Jean-François Ghiglione ${ }^{2}$ and Laetitia Hédouin $^{1}$

Observatoire Océanologique de Banyuls, Banyuls sur mer, France

${ }^{3}$ Coastal and Freshwater Group, Cawthron Institute, Private Bag 2, Nelson 7042, New Zealand

${ }^{4}$ Institute of Marine Science, University of Auckland, Private Bag 349, Warkworth 0941, New Zealand

\section{Keywords}

Absolute quantification; Endosymbionts; Holobiont; Symbiosis

\section{*Corresponding author}

Anne-Leila Meistertzheim

Laboratoire d'océanographie microbienne (LOMIC) - UMR 7621 CNRS/UPMC, Station marine de l'UPMC -

Laboratoire Arago, Avenue du Fontaule, 66650 Banyuls-sur-Mer, France

Tel: +334 688873 01, Fax: +334 688873 95, E-mail: anne-leila.meistertzheim@obs-banyuls.fr 


\section{Abstract}

Previous molecular studies have shown that many corals host a dynamic consortium of dominant and background populations of Symbiodiniaceae genotypes with putatively distinct physiological traits. In the present study, we developed a quantitative PCR assay combined with High Resolution Melting analysis (qPCR-HRM) to distinguish which Symbiodiniaceae clades are present in a sample. Because the qPCR-HRM used in isolation yielded identical melt profiles for both clades A and C, this analysis was then coupled with further specific qPCR assays to enable the absolute quantification of all Symbiodiniaceae clades and host cells. When the assays were applied to in hospite samples, they had an absolute quantification level corresponding to one coral embryo of two cells and 1,000 symbiont cells. The assays were successful on coral fragments from twelve species (eight families). We then used the qPCR-HRM assay in an ecological survey of Acropora pulchra at different spatial scales (within colony, between colonies and between sites). Differences in abundance and composition of Symbiodiniaceae clades in A. pulchra were observed at all spatial scales, suggesting that various environmental factors drove changes in Symbiodiniaceae assemblages among and within coral colonies. The qPCR-HRM assay developed in this study is a relatively simple, cost-effective and reproducible tool that can be used to accurately differentiate and quantify endosymbiont Symbiodiniaceae clades in coral in the field. This will provide new insights into coral-symbiont shuffling mechanisms and the resilience of coral colonies to environmental stressors.

\section{Introduction}

Coral reefs provide niches for $25 \%$ of all marine species but occupy only $0.2 \%$ of the world's ocean surface area, and are therefore important hot spots of biodiversity (Reaka-Kudla 1997; Spalding and Grenfell 1997; Spalding et al. 2001). In nutrient poor environments, coral reefs depend on obligate symbiotic associations between corals and photosynthetic unicellular dinoflagellates in the family Symbiodiniaceae. This family is currently classified into nine divergent lineages, hereafter referred to as clades A to I (sensu Pochon and Gates 2010), of which seven have recently been elevated to genus level (Lajeunesse et al. 2018), and six are found in symbiosis with scleractinian corals (A-D, F and G; 
Stat et al. 2008; Cooper et al. 2011a). Each Symbiodiniaceae clade encompasses significant within-clade genetic diversity (Pettay and Lajeunesse, 2013; Thornhill et al., 2017) corresponding to multiples species or types (Coffroth and Santos 2005). Experimental and field-based studies of coral bleaching events have shown that the physiology of the coral host is influenced by the genotypes of associated Symbiodiniaceae (Rowan 2004; Berkelmans and van Oppen 2006; Stat et al. 2006; Howells et al. 2012, 2013). For example, corals dominated by clade A symbionts were described as more prone to parasitism (Stat et al. 2008), whereas associations with clade C improved overall growth (Little et al. 2004; Cantin et al. 2009), and with type D1a (Durusdinium trenchii sensu LaJeunesse et al. 2018) thermo-tolerance was enhanced (Baker 2004; Stat and Gates 2011).

The association between a coral and several Symbiodiniaceae clades, often results in the presence of one dominant clade together with several background clades. The formation of partnerships between a coral and dominant Symbiodiniaceae clades often appears stable (Thornhill et al. 2009; LaJeunesse et al. 2010), and possibly driven by environmental conditions (Bongaerts et al. 2013; Tonk et al. 2014; Kennedy et al. 2016). However, the ability of corals to associate with multiple symbiont assemblages has been shown to be more widespread than previously reported (Silverstein et al. 2012).

The fragile symbiosis between corals and zooxanthellae is undergoing drastic changes due to shifting environmental conditions (Hughes et al. 2003; Hoegh-Guldberg et al. 2007). Rising seawater temperatures has led to an increase in stress-induced symbiosis breakdowns, also known as coral bleaching. Several massive coral bleaching events have been reported, resulting in a worldwide coral loss of $16 \%$ in 1998 (Wilkinson 2000). The most recent event was related to intense drought linked to El Niño (2015/2016), which resulted in the third worst worldwide mass bleaching event (National Oceanic and Atmospheric Administration [NOAA] Coral ReefWatch program 2016). The impact of this event is still incomplete but it is believed that it was the most severe coral bleaching event on record in the Great Barrier Reef (Hughes et al. 2017; NOAA Coral ReefWatch program 2017). During abnormally high seawater temperatures, certain coral species are more resistant to bleaching than others, and some bleached corals can recover (e.g. Jones et al. 2008). This observed resilience may be due to the capability 
of some corals to 'switch' their symbionts (the uptake of more tolerant symbionts from the surrounding environment) or 'shuffle' their existing assemblage composition (background taxa may become abundant in higher temperatures; Baker 2003, 2004; LaJeunesse et al. 2009).

Few studies have investigated the impact of changes in background symbiont composition and density on coral stress resistance (e.g. Cunning and Baker 2012, 2014), and how this composition shifts after bleaching events (Cunning and Baker 2012; McGinley et al. 2012; Cunning et al. 2015a, 2016; Bay et al. 2016). It has been shown that the Symbiodiniaceae taxonomic composition may change within a coral colony (Ulstrup et al. 2007; Kemp et al. 2008, 2014). However, variation in absolute abundances (symbionts normalized to host parameters, such as units of DNA or cell numbers) of the nine Symbiodiniaceae clades remains unexplored. Development of a method to accurately measure absolute abundances of all nine Symbiodiniaceae clades would enable significant advancements in our understanding of the functional role of symbiont assemblages in coral symbiosis (Cunning and Baker 2014).

Quantitative PCR (qPCR) allows the description of the relative abundance of different symbiont clades, based on the number of copies of specific DNA loci within a sample (Ulstrup and Van Oppen 2003; Loram et al. 2007; Mieog et al. 2007). It has previously enabled the effective tracking of symbiont communities dynamics from five symbiont clades (A, B, C, D and F), that were standardized to host cells (Cunning and Baker 2012, Cunning et al., 2015a, Mieog et al. 2009). It has also enabled detection of low-abundance Symbiodiniaceae genotypes associated with corals (Silverstein et al. 2012; Rouzé et al. 2016) that were previously thought to harbor only a single dominant clade (Goulet 2007; but see Baker and Romanski 2007 and Mieog et al. 2007). However, absolute quantification of all Symbiodiniaceae clades had not yet been achieved because of; $i$ ) the lack of a robust and efficient DNA extraction method applicable to a wide range of sample types (cells/polyps, colonies, and replicate), ii) the inability of qPCR assays to target all clades (i.e. including clades G-I) and the absence of an internalcontrol for identifying missing clades (i.e., a family-Symbiodiniaceae target), and iii) the lack of qPCR amplification efficiency measurements amongst clades and single host cells. 
A further benefit of qPCR is the ability to include High Resolution Melt curve to differentiate PCR products with different sequences. Two sequences containing at least one mutation generate fragments that rapidly denature and rejoin after PCR to form two (high-melting) homoduplexes and two (lowmelting) heteroduplexes (base-pairing mismatches). The melting properties of these double-stranded PCR products are monitored through the release of a saturating fluorescent double stranded DNA binding dye as temperatures are increased, thus forming different melting curve shapes (Wittwer et al. 2003). Homozygous variants are therefore distinguishable from each other through differences in their melting temperature. We previously demonstrated that the identification of unknown specimens is undertaken by comparing these specimens to a set of reference melting curves (Meistertzheim et al. 2012).

The aim of this study was to develop an accurate, fast and highly reliable qPCR-High Resolution Melting (qPCR-HRM) assay that could be coupled with further qPCR assays to distinguish and quantify the nine Symbiodiniaceae clades in a wide range of coral taxa. For this purpose, we designed seven new cladespecific primer sets and one family-Symbiodiniaceae primer set, which were tested on a range of cultures and pure DNA samples from each of the nine existing Symbiodiniaceae clades. Additionally, two coralspecific (actin and nuclear ribosomal) primer sets were designed and used on Symbiodiniaceae-free embryos of Acropora pulchra to produce host standard curves for the quantification of coral cells. We validated our assay on colony fragments from twelve different species representing eight different families, and undertook an ecological survey of $A$. pulchra at different micro- and macro-scales (within colonies, between colonies and among sites).

\section{Material and methods}

\section{Primer development}

Alignment of 135 sequences of the nuclear large sub-unit ribosomal (28S) rRNA gene, including the 5' regions of the 5.8S and Internal Transcribed Spacer 2 (ITS2), were performed using MEGA6 (Tamura 
et al. 2013). Seven clade-specific forward/reverse primer sets were designed using Primer Express v2.0 software (Applied Biosystems). The primers targeted an approximately 70-150 nucleotides [nt] region, one of the forward or reverse primer being located near the 3' end of the 5.8S rRNA gene or the 5' end of the 28S rRNA gene, and the corresponding reverse or forward primer being located in the ITS2 region (see Table 1). We also used previously published primers, including SYM_VAR_5.8S2 (Hume et al, 2015), and two actin primer sets specific to clades C and D (Cunning and Baker 2012). Host-specific (coral) primers were designed using alignments of the actin and nuclear 5.8S rDNA genes from GenBank (Table S1).

HRM analysis was used to quantify the number of clades present in each sample. This requires the amplification of a variable 80-nt partial sequence of the 5.8S gene using the forward SYM_VAR_5.8S2 and reverse Symb_R primer, hereafter referred to as the family primer pair 'Symb', which targets conserved flanked areas amplifying the nine different Symbiodiniaceae clades (Table 1; Figure S1). There are between one to ten mutations among clades in this gene (Table S2), which allows the distinction between them based on melting curve shape.

\section{Absolute quantification assay development}

Primer specificity was verified using DNA isolated from Symbiodiniaceae cell cultures in their vegetative state, from DNA collections of clades G-I (Table S3), and embryos of A. pulchra. Cells from Symbiodiniaceae-free embryos at division 2 and 4 cells were obtained following the procedure described in Hédouin et al. (2015), using A. pulchra colonies that were collected in September 2012 on the fringing reefs of Moorea Island (17 30' S, $149^{\circ} 50^{\prime} \mathrm{W}$, French Polynesia, Society Archipelago, Figure 1 A-B).

We tested a new and automated extraction method, applicable to both coral embryos and polyps, which yields consistent DNA quantity between replicates and allowed successful DNA extraction from 2 cells for corals embryos. Symbiodiniaceae cultures, embryos and samples from coral colonies were lysed by mechanic action using the Y Matrix on a FastPrep Instrument (MP Biomedical, USA). Samples were 
incubated with proteinase $\mathrm{K}\left(57^{\circ} \mathrm{C}, 1 \mathrm{hr}\right)$. DNA was then isolated using a Maxwell ${ }^{\circledR}$ Blood DNA Purification Kit LEV (Promega, USA) on a Maxwell 16 MDx Instrument (Promega). DNA quality was assessed by electrophoresis on a $1 \%$ agarose gel. Total genomic DNA concentration were measured using spectrophotometry (Nanodrop ND-1000, Thermo Fisher scientific Inc., MA, USA).

Standard curves of Symbiodiniaceae and host cells were constructed to allow absolute quantification (Table S2). Living Symbiodiniaceae cells were quantified using a Scepter Handheld Automated Cell Counter system (Millipore, USA) combined with Scepter Pro software (Millipore). Automated cell counts were compared to cell counts obtained using a hemacytometer under a light microscope. DNA was extracted for each concentration as described previously. Standard curves were run in triplicate with cell concentrations of Symbiodiniaceae clades of $1 \times 10^{3}$ to $3 \times 10^{6}$ cells per DNA extraction (clades AF), and using DNA concentrations ranging between 0.5 and about 40 ng DNA $\mu \mathrm{L}^{-1}$ (clades $\mathrm{G}, \mathrm{H}$ and I). Two standard curves for the quantification of host-cells were run in triplicate using Symbiodiniaceaefree embryos with an increasing concentration of 2 to 400 cells per DNA extraction. Acropora pulchra were in their first and second division stages, and concentrations were determined by binocular microscopy.

Quantitative PCR reactions were performed in duplicate in a $10 \mu \mathrm{L}$ volume containing genomic DNA, $1 \times$ High Resolution Melting master mix (Roche Diagnostics, USA) and $0.3 \mu \mathrm{M}$ of each primer. The amplification protocol consisted of $10 \mathrm{~min}$ pre-incubation at $95^{\circ} \mathrm{C}$ followed by 40 cycles of $95^{\circ} \mathrm{C}$ for 15 $\mathrm{s}$ (ramp rate, $4.4{ }^{\circ} \mathrm{C} . \mathrm{s}^{-1}$ ), touchdown annealing from 65 to $53{ }^{\circ} \mathrm{C}$ for $15 \mathrm{~s}\left(\right.$ ramp rate, $2.2{ }^{\circ} \mathrm{C} \mathrm{s}^{-1}$ ), and extension at $72^{\circ} \mathrm{C}$ for $20 \mathrm{~s}\left(\mathrm{~s}^{-1}\right.$ ramp rate, $\left.4.4^{\circ} \mathrm{C} . \mathrm{s}^{-1}\right)$. The qPCR reactions were performed in 384-well plates using a LightCycler®480 Instrument (Roche Diagnostics, USA). After qPCR amplification, genotyping using HRM was undertaken. This consisted of a denaturing step at $95{ }^{\circ} \mathrm{C}$ for $1 \mathrm{~min}$, followed by a hybridization step at $40{ }^{\circ} \mathrm{C}$ for $1 \mathrm{~min}$. Melting curves were then constructed by ramping from 65 to $95^{\circ} \mathrm{C}$ at $0.02^{\circ} \mathrm{C} \mathrm{s}^{-1}$, taking 25 acquisitions of fluorescence measure per each degree centigrade. A negative (no-template) control was included in the PCR to detect potential DNA contamination or any formation 
of primer dimers. Primer specificity was evaluated using qPCR analysis, gel electrophoresis and bidirectional sequencing of each positive qPCR product.

For each $\mathrm{qPCR}$ reaction, the crossing point $(\mathrm{Cp}$; corresponding to the cycle threshold $[\mathrm{Ct}]$ ) was determined using the "second derivative max method" implemented in the LightCycler ${ }^{\circledR} 480$ v.1.5.0 Software (Roche Diagnostics). The threshold for Ct calculation and normalization regions (leading and trailing ranges) for qPCR-HRM analysis were defined for each Symbiodiniaceae clade and host locus using serial dilutions of DNA and standard curves. Only successfully amplified samples with a Cp value within the linear part of the standard curves were considered for further analysis (Bustin et al. 2009). Individual qPCR efficiencies (E) of the Symbiodiniaceae clades and host reference genes were calculated using the formula: $\mathrm{E}=10^{(-1 / \text { slope })}$, as described by Yuan et al. (2006). All primers had a qPCR efficiency between 1.84 and 2.02 (Table 1).

Conversion of quantification cycle values $C p$ into relative quantities $Q_{\text {clade }_{i}}$ was undertaken for each DNA concentrations of the standard curves $i$ using clade-specific primer pair using the modified equation described by Pfaffl (2001) without normalization by a reference gene:

$Q_{\text {clade }_{i}}=E_{\text {clade }_{i}}^{\Delta \text { Ct, } \text { lade }_{i}}$, (arbitrary unit)

where $E_{\text {clade }_{i}}$ is the amplification efficiency of the clade-specific primer couple $i$ and $\Delta \mathrm{Ct}$, clade ${ }_{i}=$ $C t_{\text {clade }_{i}}$ (calibrator) - $C t_{\text {clade }_{i}}$ (sample).

The calibrator consisted of the maximal concentration of each Symbiodiniaceae clade included in the linear part of the standard curves.

The $Q_{\text {clade }_{i}}$ was calculated for each DNA concentrations in nanograms (ng) from the linear part of each standard curve $i$, allowing the derivation of the following equation:

$D N A_{\text {clade }_{i}}=f\left(Q_{\text {clade }_{i}}\right)(\mathrm{ng})$

Similarly, the family primer pair 'Symb' was used to amplify total DNA copies of Symbiodiniaceae in one reaction such that: 
$Q_{\text {Totsymb }}=E_{\text {Symb }}^{\Delta C t, \text { Symb }},($ arbitrary unit $)$

213 The $Q_{\text {TotSymb }}$ was then calculated for each DNA concentrations from the Symbiodiniaceae standard

214 curves, subsequently allowing for the derivation of the following equation:

215

$D N A_{\text {Totsymb }}=f\left(Q_{\text {Totsymb }}\right)(\mathrm{ng})$

216 These standard curves allowed for the concentrations of each clade $i$ and total Symbiodiniaceae (per

217 cell or DNA unit) of the unknown samples to be determined (Pfaffl, 2004). We considered this method

218 as sufficiently accurate when $D N A_{\text {Symb }}=\sum_{i=1}^{9} D N A_{\text {clade }_{i}}(\mathrm{ng})$.

219 The quantity of host cells was calculated using the two $Q_{r e f_{i}}$ calculated as described above from the

220 two host reference genes. The calculated values were plotted against the linear regression of each

221 corresponding standard curve, where:

222

$Q_{\text {ref }_{i}}=E_{\text {ref }_{i}}^{\Delta C t, r e f_{i}}$, (arbitrary unit)

223 Finally, the concentration of host cells was assessed by the geometric mean of the $Q_{r e f_{i}}$ such as described by Hellemans et al., (2007) to normalize relative quantities with multiple reference genes:

$$
Q_{\text {Host }}=\sqrt{\prod_{i}^{2} Q_{r e f_{i}}}
$$

226 The $Q_{\text {Host }}$ was then calculated for each DNA concentrations from the host standard curves,

227 subsequently allowing for the derivation of the following equation:

$D N A_{\text {Host }}=\mathrm{f}\left(Q_{\text {Host }}\right)($ ng).

229 Finally, the linear part of each standard curve allowed for the quantification of both Symbiodiniaceae and its host using specific and family primers starting from a known quantity of DNA, such that

$$
D N A_{\text {Reaction }}=D N A_{\text {Host }}+D N A_{\text {Symb }}(\mathrm{ng})
$$


and

233

$D N A_{\text {Reaction }}=D N A_{\text {Host }}+\sum_{i=1}^{9} D N A_{\text {clade }_{i}}(\mathrm{ng})$

The HRM data obtained with the family-Symbiodiniaceae primers 'Symb' resulted in differences in curve shapes for each Symbiodiniaceae clade which were discriminated using the Gene Scanning module of the LightCycler 480 v.1.5.0 Software (Roche Diagnostics, USA). Melting curve data was adjusted manually as previously described (Meistertzheim et al. 2012), and normalized fluorescence conditions were established and adjusted, with the threshold set to 0 and the sensitivity at 0.26 (Lavergne et al. 2014). Curve shapes and Tm were compared between samples of the same clade and between clades. Shape similarities or differences in the melting curves between samples were assessed visually and mathematically by calculating the root-mean square error (RMSE) values. The latter were calculated by pairwise comparison of the normalized fluorescence data of melting curves obtained for each Symbiodiniaceae clade as recommended by Naue et al. (2014). The intra- and inter-run accuracy of HRM results were estimated by calculating the RMSE values of three runs of triplicate amplifications of all standard curves. The influence of template DNA was also investigated for each Symbiodiniaceae clade and embryos of A. pulchra at a DNA concentration range between $100 \mathrm{pg}$ and $500 \mathrm{ng}$. Finally, to confirm the number of clades present in one sample by HRM, DNA from various clades was mixed in different proportions to obtain reference melting curves of DNA mixtures. DNA from clades A-D, F and $\mathrm{G}$ were cross-mixed in pairs using three different proportions of DNA $(25: 75,50: 50,75: 25)$ and by using three to five clades combined at equimolar proportion, and at a final DNA concentration of $15 \mathrm{ng}$ DNA $\mu \mathrm{L}^{-1}$.

\section{Validation test of host quantification using other coral species}

We then tested the applicability of only the two coral reference genes to be applied to species other than A. pulchra because the other primer sets will target Symbiodiniaceae clades whatever the host species. 
Of the 67 scleractinian species from nine different families previously described in Moorea Island (Bosserelle et al. 2014), twelve species representing eight different families were chosen, including Acroporidae (Acropora pulchra, Astreopora sp. and Montipora capitata), Agariciidae (Pachyseris speciosa and Pavona cactus), Faviidae (Dipsastraea [Favia] stelligera), Fungiidae (Danafungia sp.), Merulinidae (Cyphastrea serailia), Pocilloporidae (Pocillopora damicornis), Poritidae (Porites rus and Napopora irregularis) and Psammocoridae (Psammocora contigua).

Two or three colony fragments (ca. $0.5-1 \mathrm{~cm}^{2}$ ) of the coral species were sampled by diving in several reef sites of Moorea and Tahiti Islands. The coral fragments were collected using wire cutters and clamps previously cleaned with sodium hydroxide and ethanol to avoid cross-contamination between samples. Each fragment was collected from the tip of each coral and fixed separately in $70 \%$ ethanol.

Coral samples were washed in DNAse-free water before performing DNA extraction, as described above. DNA was diluted to $15 \mathrm{ng} \mu \mathrm{L}^{-1}$ and $30 \mathrm{ng}$ was used to conduct qPCR-HRM assays. To ensure replicability and homogeneity, each plate contained DNA from a representative of the nine Symbiodiniaceae clades in duplicate, as well as Symbiodiniaceae-free coral embryos and a negative control.

\section{Comparison of Symbiodiniaceae assemblages in Acropora pulchra at micro and macro-scale}

Twenty colonies of A. pulchra were collected in September 2012 from Mahana $\left(17^{\circ} 29^{\prime} 18^{\prime \prime S}\right.$; $\left.149^{\circ} 53^{\prime} 7^{\prime \prime} \mathrm{W}\right)$ and Teavaro $\left(17^{\circ} 30^{\prime} 23^{\prime \prime} \mathrm{S} ; 149^{\circ} 45^{\prime} 53^{\prime \prime} \mathrm{W}\right)$, two fringing reef sites in Moorea Island (Figure 1). These two sites were chosen because A. pulchra colonies were found in high abundances at both sites despite contrasting turbidity (0.12 vs 0.04 NTU in Mahana and Teavaro sites, respectively). Turbidity, salinity, temperature, and $\mathrm{pH}$ were recorded using the multiparameter HORIBA U50 probe.

To examine the spatial distribution of symbiont clades within a host colony, branch fragments (approximately $0.5-1 \mathrm{~cm}^{2}$ ) were sampled using individual sterilized wire cutters and clamps. Coral samples were collected on both the upward and downward facing sides of coral branches, exhibiting 
two distinct color morphs (normal $[\mathrm{N}]$ and slightly bleached $[\mathrm{sB}]$ ), representing different micro-variation of the environment; Figure 1C-E). These were preserved in $70 \%$ ethanol and stored at $-20^{\circ} \mathrm{C}$ until DNA extraction. DNA extractions were undertaken as described above. Absolute quantification by qPCR assay and HRM was undertaken in duplicate using standard curves of Symbiodiniaceae clades and $A$. pulchra embryos with a no-template control in each plate.

Tests for normality and homoscedasticity on obtained DNA concentrations were performed using the Statistica software v10 (Statsoft) using Shapiro-Wilk and Levene tests. Concentration differences between coral-color fragments and sites for the number of host-cells, total Symbiodiniaceae cells, and cell counts for each specific Symbiodiniaceae clade were compared using non-parametric KruskalWallis and Mann-Whitney $U$-tests.

\section{Results}

\section{Quantification of symbiont and host cells}

Standard curves generated from increasing Symbiodiniaceae cells ranging from $1 \times 10^{3}$ to $3 \times 10^{6}$ cells per extraction resulted in DNA ranging concentrations of 1 to $200 \mathrm{ng}$ DNA $\mu \mathrm{L}^{-1}$. For all clades, there was a strong correlation between the DNA concentrations and the cell numbers with correlation coefficient $\mathrm{R}^{2}$ higher than 0.95 (e.g., for clade $C \mathrm{R}^{2}=0.96 \pm 0.03 \mathrm{SD}$; Figure S2A). Linear curves were obtained for host cell, with DNA concentrations gradually increasing (9 to $670 \mathrm{ng} \mathrm{DNA} \mu \mathrm{L}^{-1}$ ) as the number of host cells per extraction rose from 2 to $400\left(\mathrm{R}^{2}=0.996 \pm 0.004\right.$, Figure $\left.\mathrm{S} 2 \mathrm{~B}\right)$. Using $\mathrm{qPCR}$ analysis, quantification of the total number of Symbiodiniaceae cells was performed using the family primer pair 'Symb' with DNA extracted from $1 \times 10^{3}$ to $3 \times 10^{6}$ cells per extraction of all individual clades (Table S4). The resulting standard curves obtained for each clade $\left(D N A_{\text {Totsymb }}=f\left(Q_{\text {Totsymb }}\right)\right)$ indicated high correlation coefficients (mean $\mathrm{R}^{2}=0.96 \pm 0.04$; Figure $2 \mathrm{~A}$ for clade $\mathrm{C}$ ). The clade-specific Symbiodiniaceae primers, also had standard curves $\left(D N A_{\text {clade }_{i}}=f\left(Q_{\text {clade }_{i}}\right)\right)$ with high coefficient correlation values (mean $\mathrm{R}^{2}=0.96 \pm 0.04$; Figure $2 \mathrm{~A}$ for clade $\mathrm{C}$ and Table S4). We obtained similar 
specificity and efficiency $\left(E_{S y m b}\right)$ for qPCR amplifications tested on representative samples from each of the nine clades using the family primers 'Symb' (Table S5), suggesting that these loci are conserved within Symbiodiniaceae lineages. Host standard curves, which allowed for the quantification of polyp cells, were constructed ( 2 to 200 cells; Figure 2B) with the highest accuracy obtained between 2 and 50 cells $\left(\mathrm{R}^{2}=0.98 \pm 0.02\right)$, corresponding to DNA concentrations ranging between 10 and $90 \mathrm{ng} \mathrm{DNA} \mu \mathrm{L}^{-1}$ (Figure S2B). No DNA amplification was obtained from embryos cells when using primers designed for Symbiodiniaceae, or from dinoflagellates cells when using primers designed for host genes. Duplicates produced gap values between both Ct lower than 0.5 .

\section{Reproducibility, accuracy and specificity of the High Resolution Melt curve genotyping}

The HRM assay using the family locus of 5.8S rDNA for the entire genus Symbiodiniaceae allowed for correct discrimination between all clades except clades A and $\mathrm{C}$ when compared to the selected cell cultures and DNA collection (Table S2). Discrimination was explored by visual inspection of the melting curves (Figure 3A and 3B) and by calculating RMSE values (Figure 3C). The visual and mathematical distinction between clades was clearly visible for all Symbiodiniaceae lineages explored in this study, except for clades A and C. However, when different clades are co-occurring, the method effectively detected the presence of heteroduplexes (e.g. AC; see below). Symbiodiniaceae identification by HRM using the family-specific primer pair (Symb) on material derived from cell cultures always corroborated the results from clade-specific primers. The Tm of all analyzed samples ranged between $82^{\circ} \mathrm{C}$ and $84^{\circ} \mathrm{C}$ (Figure $3 \mathrm{~A}$ ). Seven clades were easily identifiable and the mean RMSE values for comparisons of samples from the nine clades (Figure 3C) ranged from $2.70( \pm 0.16)$ to 32.56 $( \pm 0.03)$, corresponding to the number of mutations (1-13, Table S3). The lowest RMSE values were obtained when comparing clades $\mathrm{A}$ and $\mathrm{C}$ (mean $0.84 \pm 0.09$ ), whose sequences differed by five mutations (Table 2). Although up to two mutations were present within the reverse (SymbR) primer region (Figure S1), similar amplification efficiencies were obtained using the family primer in the cladespecific standard curves (Figure 2), highlighting similar amplification efficiencies between clades 
(Table S5). No DNA amplification was obtained from our negative controls. Nine replicate reactions per clade and per experimental run, including standard curves of cell cultures and triplicate DNA samples, yielded similar $\mathrm{Ct}$ values $(\Delta \mathrm{Ct}<0.5)$ and similar melting curves corresponding to low RMSE for intra- and inter-run comparisons (mean values of $1.0 \pm 0.3$ and $2.2 \pm 0.6$, respectively). Similar melting curve shapes were obtained among sub-clade genotypes (Table S2) within five clades (A, B, F, $\mathrm{G}$ and $\mathrm{H}$ ), with RMSE values intra-clades ranging from 0.09 to 2.12 (mean value of $1.25 \pm 0.46$ ) (Table S5).

\section{Limits of the High Resolution Melt curve method and application to coral tissue samples}

We obtained similar melting curve shapes for the nine Symbiodiniaceae clades, with DNA concentrations ranging from $100 \mathrm{pg}$ to $500 \mathrm{ng}$ and a mean RMSE value of $0.68 \pm 0.37$. It indicated that low template DNA concentration did not significant change the melting curve shapes. Melting curves obtained using experimental mixtures of pairwise clade DNA comparisons (using mixed combinations among clades A, B, C, D and F) always displayed more than two peaks, including the mixture of A and $\mathrm{C}$, thus confirming the presence of two different DNA amplifications and their corresponding homoduplexes and heteroduplexes in the reaction (Figure 4A). DNA mixed in the same proportions using three, four and/or five clades always yielded melting curve shapes with three peaks regardless of the proportions used (Figure 4B), confirming the presence of three or more clades in a reaction which was further validated by three or more positive amplifications using the specific primers. However, the intensity of both peaks changed when applying variable proportions of two clades (Figure 4C).

The method assumes that the copy number of the locus targeted by the qPCR primers is the same within each clade. However, further investigations are required whether this assumption is valid and can be applied to the absolute quantification of all clades in coral samples. 
359 For the twelve coral species, amplifications of the host DNA using the host-specific primer sets were 360 positive regardless of the coral species investigated in this study. The $\mathrm{Cp}$ values of the host primer set 361 (host genes) always fell within the constructed standard curves using A. pulchra embryos, i.e. less than

362

363 30 PCR cycles (data not shown).

\section{Field survey of Acropora pulchra at micro and macro-scales}

We analyzed a total of 40 fragments of A. pulchra collected from two sites (Mahana and Teavaro) and including two distinct color morphs. Out of the nine existing Symbiodiniaceae clades, only three (A, C, and D) were detected using the qPCR-HRM assay (Figures 5 and 6). Colonies showed significantly higher concentrations of total Symbiodiniaceae DNA per total DNA in Mahana compared to Teavaro (mean of $D N A_{\text {Totsymb }} \pm \mathrm{SD}=12.1 \% \pm 3.0 \%$, and $7.1 \% \pm 1.3 \%$, respectively, Mann-Whitney $U$-test, $\mathrm{p}<0.001)$. The values were similar between the normal and slightly bleached coral fragments within a site (Figure 5). Concentrations of clade A cells were 2-fold higher in colonies from Mahana compared to Teavaro (mean $6.5 \% \pm 1.6 \%$ and $2.7 \% \pm 0.4 \%$, respectively; Mann-Whitney $U$-test, $\mathrm{p}<0.001$ ). Clade $\mathrm{C}$ cells were identified almost exclusively in colonies from Teavaro at a mean concentration of $7 \% \pm$ $1 \%$, except for two colonies in Mahana with medium color loss (Figure 6). For these two colonies, fragments collected from a branch (above $v s$ below) harbored different proportions of Symbiodiniaceae (8.2\% vs 5.4\%, $0 \%$ vs $3.0 \%$ and $5.6 \%$ vs $2.6 \%$, for clades A, C and D, respectively, Figure 6). In contrast, clade D cells were detected exclusively from Mahana colonies (mean 4.8\% $\pm 2.6 \%$ ).

\section{Discussion}

\section{Quantitative PCR-High Resolution Melt assay}

This study developed a new qPCR-HRM assay to explore Symbiodiniaceae clades present in a coral fragment smaller than $1 \mathrm{~cm}^{2}$. This assay was coupled with further clade and host specific assays and allowed, for the first time, the absolute quantification of the proportions of each Symbiodiniaceae clade 
in coral tissues normalized by the number of host cells. This quantification was based on standard curves generated using Symbiodiniaceae-free coral cells and representative DNA or cultures from each of the nine existing clades, the latter being haploid in vegetative stage in both cultured and in hospite (Santos and Coffroth 2003). The method assumes that copy number of the locus targeted by the qPCR primers is the same in the cells used as the standard curve template and the cells present in the unknown sample (within each clade). This allows for the establishment of a correlative relationship between the number of living cells in each clade and qPCR values. However, additional research is required to confirm this assumption.

The qPCR-HRM assay developed in the present study provides a simple way to identify which clades are present in mixed environmental samples. Granados-Cifuentes and Rodriguez-Lanetty (2011) showed that HRM is a more effective option, than relatively time-consuming molecular fingerprinting methods such as Denaturing Gradient Gel Electrophoresis for identifying mixed-clade combinations. Our results demonstrated that HRM is able to identify each Symbiodiniaceae clade in isolation but failed to differentiate clades $\mathrm{A}$ and $\mathrm{C}$ due to their identical melting curves. Two amplicons can have the same melting behavior despite sequences not being exactly the same, e.g., due to an erasing effect caused by two mutations (e.g. T to G and G to T) (Druml and Cichna-Markl 2014). However, the present study also demonstrated that when different clades are mixed together, including the mixing of $\mathrm{A}$ and $\mathrm{C}$, heteroduplexes are always produced which are easily detectable by HRM because they alter the shape of the melting curves (Wittwer et al. 2003). Our HRM results were also corroborated by clade-specific qPCR amplifications. By combining HRM with qPCR, we gained insights into the absolute quantification of the coral polyp and its symbiont cladal content. Quantitative PCR analyses has previously been described as a powerful method for quantifying Symbiodiniaceae clades A-F (Loram et al. 2007; Mieog et al. 2007; Bay et al. 2016; Rouzé et al. 2016, 2017). These studies quantified the relative proportion of PCR amplicons from each symbiotic clade, standardizing their assays using a single host gene. However, there was no in-depth assessment of the potential effect additional clades (i.e., G, H, and I) may have on the overall assay. Furthermore, differential efficiencies of PCR amplification among clades and host cells were not taken into account possibly leading to an 
underestimation of clade proportions. These assays also lacked total Symbiodiniaceae cell internal controls. The assay described in the present study quantifies host cells through amplification of two conserved reference host genes, and we showed that this could be applied to twelve coral species representing eight different coral families. Using specific and family primers of the nine Symbiodiniaceae clades and two host genes to construct standard curves of symbiotic and host cells, our method quantifies the total abundance of Symbiodiniaceae and each specific clade composition, normalized per host parameters, in terms of DNA values (in nanograms) or cell numbers, as previously recommended (Cunning and Baker 2014).

\section{Limitations}

Using high concentrations of DNA can lead to misidentification of clades when using qPCR-HRM assays (Granados-Cifuentes and Rodriguez-Lanetty 2011). In the present study, the upper limit of DNA templates for the assay was not reached with maximal values of DNA for embryos at $670 \mathrm{ng} . \mu \mathrm{L}^{-1}$ and Symbiodiniaceae at $200 \mathrm{ng} . \mu \mathrm{L}^{-1}$. We also obtained accurate and reproducible results with $30 \mathrm{ng}$ of total DNA extracted from each coral fragment. The lower limit of the method corresponded to one embryo of two cells, and to $10^{3}$ cells of Symbiodiniaceae. This limit is lower than population sizes measured within planulae (7.4.104 in $1 \mathrm{~mm}$ long; Marshall 1932) or within individual fragments of coral colony $\left(\sim 10^{6}\right.$ cells $\mathrm{cm}^{-2}$; Fitt et al. 2000). This method is therefore particularly useful for accurately detecting background Symbiodiniaceae clades within a sample. Unlike High-Throughput Sequencing (HTS) methods (Arif et al. 2014; Edmunds et al. 2014; Quigley et al. 2014; Thomas et al. 2014; Boulotte et al. 2016; Hume et al. 2018), our assay is unable to provide information on the total genetic diversity of within-clade assemblages. Nevertheless, HTS methods are relatively costly and time-consuming compared to the qPCR-HRM method presented here, which requires fewer processing steps and produces results within hours and at relatively low cost. This method may effectively complement HTS studies when dealing with large numbers of small individual samples (Cousins et al. 2012; Cristescu 2014). 
439

440

441

The ecological role of dominant Symbiodiniaceae genotypes in coral host physiology and stress tolerance has been extensively studied (Rowan and Knowlton 1995; Baker 2003; Coffroth and Santos 2005; Stat et al. 2012). However, there is very limited understanding of the natural variability in Symbiodiniaceae cladal abundance distribution in hospite, due to micro-environmental conditions (Wangpraseurt et al. 2014, 2015; Cunning et al. 2015b). By applying the qPCR-HRM assay developed in this study we explored the abundance and repartitioning of Symbiodiniaceae clades at different spatial scales in A. pulchra. Our work revealed that the composition of Symbiodiniaceae clade assemblages in this coral species varied at all spatial scales investigated, including geographical (between two sites), inter-colony (within each site), and intra-colony (upward versus downward facing surface of the branch), confirming the high degree of spatial variation in endosymbiotic associations with Acropora species (Ulstrup and Van Oppen 2003; Ulstrup et al. 2007; Rouzé et al. 2017).

At the geographical scale, significantly higher abundance of total Symbiodiniaceae were observed in A. pulchra originating from Mahana compared to Teavaro. The abundance of symbiont types can be enhanced by various environment factors, such as nutrient levels or turbidity (Fabricius 2005; Cooper et al. 2011a). The higher total Symbiodiniaceae abundance at the Mahana site, which was characterized by higher turbidity corroborates the findings of Bay et al. (2016) that higher Symbiodiniaceae abundance in corals transplanted to inshore locations which are commonly associated with higher dissolved nutrients. As previously observed in Moorea (Rouzé et al. 2017), up to three distinct clades were detected in a single A. pulchra colony, which contrasts with findings of Thomas et al. (2014) who reported exclusive clade C dominance in A. pulchra colonies from Western Australia. In the present study, significant differences in the proportion of Symbiodiniaceae clades between sites were observed with a co-dominance of clades A and C in Teavaro compared to multi-clades A and D and clades A, C and D in Mahana. Despite the similar temperatures measured at both sites, (ranging from 28.7 to $28.9^{\circ} \mathrm{C}$ ), a higher solar irradiance was recorded at Teavaro (average value: 1767 vs $2040 \mu \mathrm{mol}$ 
$463 \mathrm{~s}^{-1} \mathrm{~m}^{2}$ ). Coral bleaching is often observed when high temperature and solar irradiance levels occur in 464 combination (Brown and Dunne 2008). It has also been shown that, in addition to the symbiont identity, 465 the abundance of Symbiodiniaceae cells within a coral may play a key role in influencing the function 466 of coral-algal symbiosis, with clade $\mathrm{C}$ abundant corals being more prone to bleaching than those with 467 abundant clade D or background C in branched corals (Cunning and Baker 2012; Cunning et al. 2016). 468 As such, the lower total Symbiodiniaceae density observed in the clade C dominated A. pulchra colonies 469 from Teavaro (i.e., with higher light levels), could be the result of a mild bleaching event at that location, contrasting with the colonies at Mahana where the putative 'thermo-tolerant' clade D and 'opportunistic' clade A co-dominated and were present at higher densities. Symbiodiniaceae genotypes may be advantageous under stable conditions (see Putnam et al. 2012), the high incidence of clade A reported here in both studied sites may represent a lower resilience potential of coral species from Moorea lagoons. It has been suggested that a higher proportion of clade A in corals could increase their susceptibility to disease and Vibrio spp. colonization (Rouzé et al. 2016). The omnipresence of clade A symbionts in A. pulchra from both sites is of concern for the health and future of corals in Moorea. Understanding the factors that trigger shifts in Symbiodiniaceae clades abundance and composition in corals around Moorea, through long-term analysis at different spatio-temporal scales, is an interesting avenue for future research. distribution of in hospite Symbiodiniaceae clades at the micro-scale (i.e., within a colony), but without taking into account the absolute abundances of each clade and without measuring background symbiont genotypes. Interestingly, $22 \%$ of fragments collected from a branch (above $v s$ below) of the same colony from Mahana harbored different proportions of Symbiodiniaceae. In this study, micro-scale variations revealed the presence of C-type populations in coral fragments originating from Mahana with lighter colors located below (shaded) compared to the ones located above branches. Although research efforts have focused on revealing the flexibility of coral symbiosis to changing environments and the existence 
given to intra-colony variation. Rowan et al. (1997) emphasized intra-colony zonation of Symbiodiniaceae communities in response to environmental irradiance, suggesting micro-scale physiological acclimatization at the level of colony. Skeletal and tissue properties of corals alter in hospite light and oxygen availability to Symbiodiniaceae cells (Wangpraseurt et al. 2014, 2015), creating different niches at the micro-scale and favoring the establishment of different symbiotic clade partnerships that may help corals adapt to the prevailing conditions (Kemp et al. 2008; Suggett et al. 2015). Our study reinforces earlier researches emphasizing the importance of intra-colony variation of Symbiodiniaceae and provides insights into the partitioning of Symbiodiniaceae clades within colonies of A. pulchra. Our work highlights the importance of considering micro-niches in studies linking symbiont diversity and coral response to environmental stress to assist in accurately predicting the impact of rising seawater temperature on coral populations and community responses.

In the present study, we developed and validated a qPCR-HRM assay. When coupled with clade and host specific qPCRs, it enabled the absolute quantification of endosymbiotic Symbiodiniaceae from all the nine clades from small coral samples, using the combination of family-Symbiodiniaceae and clades-specific primer sets. The method has the potential to provide useful data on the abundance and repartition of the endosymbiont clades at different biological scales (cells, polyp, colony, population and species), as well as different temporal and spatial scales, which may help understand the drivers behind symbiont community changes (Chen et al. 2005), or those following bleaching events (Thornhill et al. 2006). The method provides a new tool to describe the complexity of coral-Symbiodiniaceae symbiosis in a rapidly changing world. For example, it may contribute to elucidating the mechanisms governing symbiont shuffling as a result of frequent cumulative thermal stress and be useful to quantify horizontal and vertical transmission of symbionts from parental colonies to larvae, thus providing crucial information for restoration applications. 
Sincere thanks are due to Prof. Mary-Alice Coffroth from State University of New York at Buffalo

517

518

519

520

(USA) and Dr. Hollie Putnam from University of Rhode Island (USA) for providing us with Symbiodiniaceae cultures and DNA samples, as well as Dr. Sarah Nahon from French National Institute for Agricultural Research (France) for providing pictures. The authors would like to thank the staff of the CRIOBE for their help during the experiments, and especially Antoine Puisay for his help in sampling corals.

\section{Conflict of Interest:}

The authors declare that they have no conflict of interest.

\section{Ethical approval:}

All applicable international, national, and/or institutional guidelines for the care and use of animals were followed. Coral collection was performed according to the French Polynesia regulation.

\footnotetext{
Arif C, Daniels C, Bayer T, Banguera-Hinestroza E, Barbrook A, Howe CJ, LaJeunesse TC, Voolstra CR (2014) Assessing Symbiodinium diversity in scleractinian corals via next-generation sequencing-based genotyping of the ITS2 rDNA region. Mol Ecol 23:4418-4433
}

Baker AC (2003) Flexibility and specificity in coral-algal symbiosis: Diversity, ccology , and biogeography of Symbiodinium. Annu Rev Ecol Evol Syst 34:661-689

Baker AC (2004) Symbiont diversity on coral reefs and its relationship to bleaching resistance and resilience. Corail health and diseases. Springer, pp 177-191

Baker AC, Romanski AM (2007) Multiple symbiotic partnerships are common in scleractinian corals, but not in octocorals: Comment on Goulet (2006). Mar Ecol Prog Ser 335:237-242

Bay LK, Doyle J, Logan M, Berkelmans R (2016) Recovery from bleaching is mediated by threshold densities of background thermo-tolerant symbiont types in a reef-building coral. R Soc Open Sci $3: 160322$

Berkelmans R, van Oppen MJH (2006) The role of zooxanthellae in the thermal tolerance of corals: a 

"nugget of hope" for coral reefs in an era of climate change. Proc R Soc London B Biol Sci 273:2305-2312

Bongaerts P, Frade PR, Ogier JJ, Hay KB, van Bleijswijk J, Englebert N, Vermeij MJA, Bak RPM, Visser PM, Hoegh-Guldberg O (2013) Sharing the slope: depth partitioning of agariciid corals and associated Symbiodinium across shallow and mesophotic habitats $(2-60 \mathrm{~m})$ on a Caribbean reef. BMC Evol Biol 13:205

Bosserelle P, Berteaux-Lecellier V, Chancerelle Y, Hédouin L, Nugues M, Wallace C, Pichon M (2014) Guide d'identification des coraux de Moorea. CRIOBE.

Boulotte NM, Dalton SJ, Carroll AG, Harrison PL, Putnam HM, Peplow LM, van Oppen MJ (2016) Exploring the Symbiodinium rare biosphere provides evidence for symbiont switching in reefbuilding corals. ISME J 10:2693-2701

Brown BE, Dunne RP (2008) Solar radiation modulates bleaching and damage protection in a shallow water coral. Mar Ecol Prog Ser 362:99-107

Bustin SA, Benes V, Garson JA, Hellemans J, Huggett J, Kubista M, Mueller R, Nolan T, Pfaffl MW, Shipley GL, Vandesompele J, Wittwer CT (2009) The MIQE guidelines: minimum information for publication of quantitative real-time PCR experiments. Clin Chem 55:611-22

Cantin NE, van Oppen M, Willis BL, Mieog JC, Negri AP, Oppen MJH, Willis BL, Mieog JC, Negri AP (2009) Juvenile corals can acquire more carbon from high-performance algal symbionts. Coral Reefs 28:405-414

Chen CA, Wang J-T, Fang L-S, Yang Y-W (2005) Fluctuating algal symbiont communities in Acropora palifera (Scleractinia: Acroporidae) from Taiwan. Mar Ecol Prog Ser 295:113-121

Coffroth MA, Santos SR (2005) Genetic diversity of symbiotic dinoflagellates in the genus Symbiodinium. Protist 156:19-34

Cooper TF, Berkelmans R, Ulstrup KE, Weeks S, Radford B, Jones AM, Doyle J, Canto M, O'Leary RA, van Oppen MJH (2011a) Environmental factors controlling the distribution of Symbiodinium harboured by the coral Acropora millepora on the great barrier reef. PLoS One 6 (10): e25536.

Cooper TF, Ulstrup KE, Dandan SS, Heyward AJ, Kühl M, Muirhead A, O’Leary RA, Ziersen BEF, Van Oppen MJH (2011b) Niche specialization of reef-building corals in the mesophotic zone: metabolic trade-offs between divergent Symbiodinium types. Proc R Soc B Biol 278:1840-1850

Cousins MM, Ou S-S, Wawer MJ, Munshaw S, Swan D, Magaret C a, Mullis CE, Serwadda D, Porcella SF, Gray RH, Quinn TC, Donnell D, Eshleman SH, Redd AD (2012) Comparison of a High Resolution Melting (HRM) Assay to Next Generation Sequencing for Analysis of HIV Diversity. J Clin Microbiol 50:3054-3059

Cristescu ME (2014) From barcoding single individuals to metabarcoding biological communities: towards an integrative approach to the study of global biodiversity. Trends Ecol Evol 29:566571

Cunning R, Baker AC (2012) Excess algal symbionts increase the susceptibility of reef corals to bleaching. Nat Clim Chang 3:259-262

Cunning R, Baker AC (2014) Not just who, but how many: the importance of partner abundance in reef coral symbioses. Front Microbiol 5:400

Cunning R, Ritson-Williams R, Gates R (2016) Patterns of bleaching and recovery of Montipora capitata in Kāne'ohe Bay, Hawai' i, USA. Mar Ecol Prog Ser 551:131-139 
Cunning R, Silverstein RN, Baker AC (2015a) Investigating the causes and consequences of symbiont shuffling in a multi-partner reef coral symbiosis under environmental change. Proc R Soc London B Biol Sci 282:20141725

Cunning R, Vaughan N, Gillette P, Capo TR, Matté JL, Baker AC, Maté JL, Baker AC (2015b) Dynamic regulation of partner abundance mediates response of reef coral symbioses to environmental change. Ecology 96:1411-20

Druml B, Cichna-Markl M (2014) High resolution melting (HRM) analysis of DNA - Its role and potential in food analysis. Food Chem 158:245-254

Edmunds PJ, Adjeroud M, Baskett ML, Baums IB, Budd AF, Carpenter RC, Fabina NS, Fan T-Y, Franklin EC, Gross K, Han X, Jacobson L, Klaus JS, McClanahan TR, O'Leary JK, van Oppen MJH, Pochon X, Putnam HM, Smith TB, Stat M, Sweatman H, van Woesik R, Gates RD (2014) Persistence and Change in Community Composition of Reef Corals through Present, Past, and Future Climates. PLoS One 9:e107525

Fabricius KE (2005) Effects of terrestrial runoff on the ecology of corals and coral reefs: review and synthesis. Mar Pollut Bull 50:125-146

Fitt WK, McFarland FK, Warner ME, Chilcoat GC (2000) Seasonal patterns of tissue biomass and densities of symbiotic dinoflagellates in reef corals and relation to coral bleaching. Limnol Oceanogr 45:677-685

Goulet TL (2007) Most scleractinian corals and octocorals host a single symbiotic zooxanthella clade. Mar Ecol Prog Ser 335:243-248

Granados-Cifuentes C, Rodriguez-Lanetty M (2011) The use of high-resolution melting analysis for genotyping Symbiodinium strains: a sensitive and fast approach. Mol Ecol Resour 11:394-399

Hédouin L, Pilon R, Puisay A (2015) Hyposalinity stress compromises the fertilization of gametes more than the survival of coral larvae. Mar Environ Res 104:1-9

Hellemans J, Mortier G, De Paepe A, Speleman F, Vandesompele J (2007) qBase relative quantification framework and software for management and automated analysis of real-time quantitative PCR data. Genome Biol 8:R19

Hoegh-Guldberg O, Mumby PJ, Hooten AJ, Steneck RS, Greenfield P, Gomez E, Harvell CD, Sale PF, Edwards AJ, Caldeira K (2007) Coral reefs under rapid climate change and ocean acidification. Science (80) 318:1737

Howells EJ, Beltran VH, Larsen NW, Bay LK, Willis BL, van Oppen MJH (2012) Coral thermal tolerance shaped by local adaptation of photosymbionts. Nat Clim Chang 2:116-120

Howells EJ, Willis BL, Bay LK, Van Oppen MJH (2013) Spatial and temporal genetic structure of Symbiodinium populations within a common reef-building coral on the Great Barrier Reef. Mol Ecol 22:3693-3708

Hughes TP, Baird AH, Bellwood DR, Card M, Connolly SR, Folke C, Grosberg R, Hoegh-Guldberg O, Jackson JBC, Kleypas JA, Lough JM, Marshall P, Nyström M, Palumbi SR, Pandolfi JM, Rosen B, Roughgarden J, Nystrom M (2003) Climate change, human impacts, and the resilience of coral reefs. Science (80) 301:929-933

Hughes TP, Kerry JT, Álvarez-Noriega M, Álvarez-Romero JG, Anderson KD, Baird AH, Babcock RC, Beger M, Bellwood DR, Berkelmans R, Bridge TC, Butler IR, Byrne M, Cantin NE, Comeau S, Connolly SR, Cumming GS, Dalton SJ, Diaz-Pulido G, Eakin CM, Figueira WF, Gilmour JP, Harrison HB, Heron SF, Hoey AS, Hobbs J-PA, Hoogenboom MO, Kennedy E V, Kuo C, Lough JM, Lowe RJ, Liu G, McCulloch MT, Malcolm HA, McWilliam MJ, Pandolfi 
JM, Pears RJ, Pratchett MS, Schoepf V, Simpson T, Skirving WJ, Sommer B, Torda G, Wachenfeld DR, Willis BL, Wilson SK (2017) Global warming and recurrent mass bleaching of corals. Nature 543:373-377

Hume BCC, D'Angelo C, Smith EG, Stevens JR, Burt J, and Wiedenmann J. 2015. Symbiodinium thermophilum sp nov., a thermotolerant symbiotic alga prevalent in corals of the world's hottest sea, the Persian/Arabian Gulf. Scientific Reports 5:08562

Hume BCC, Ziegler M, Poulain J, Pochon X, Romac S, Boissin E, de Vargas C, Planes S, Wincker P, Voolstra CR (2018) An improved primer set and amplification protocol with increased specificity and sensitivity targeting the Symbiodinium ITS2 region. PeerJ 6:e4816.

Jones AM, Berkelmans R, van Oppen MJH, Mieog JC, Sinclair W (2008) A community change in the algal endosymbionts of a scleractinian coral following a natural bleaching event: field evidence of acclimatization. Proc R Soc B Biol 275:1359-1365

Kemp DW, Fitt WK, Schmidt GW (2008) A microsampling method for genotyping coral symbionts. Coral Reefs 27:289-293

Kemp DW, Hernandez-Pech X, Iglesias-Prieto R, Fitt WK, Schmidt GW (2014) Community dynamics and physiology of Symbiodinium spp. before, during, and after a coral bleaching event. Limnol Ocean 59:788-797

Kennedy E V, Tonk L, Foster NL, Chollett I, Ortiz J-C, Dove S, Hoegh-Guldberg O, Mumby PJ, Stevens JR (2016) Symbiodinium biogeography tracks environmental patterns rather than host genetics in a key Caribbean reef-builder, Orbicella annularis. Proc R Soc B Biol Sci 283: 20161938.

LaJeunesse TC, Smith R, Walther M, Pinzón J, Pettay DT, McGinley M, Aschaffenburg M, MedinaRosas P, Cupul-Magaña AL, Pérez AL, Reyes-Bonilla H, Warner ME (2010) Host-symbiont recombination versus natural selection in the response of coral-dinoflagellate symbioses to environmental disturbance. Proc Biol Sci 277:2925-2934

LaJeunesse TC, Parkinson JE, Gabrielson PW, Jeong HJ, Reimer JD, Voolstra CR, Santos SR (2018). Systematic revision of Symbiodiniaceae highlights the antiquity and diversity of coral endosymbionts. Curr Biol 28:1-11

Lavergne E, Calves I, Meistertzheim AL, Charrier G, Zajonz U, Laroche J (2014) Complex genetic structure of a euryhaline marine fish in temporarily open/closed estuaries from the wider Gulf of Aden. Mar Biol 161:113-1126

Little AF, van Oppen MJH, Willis BL (2004) Flexibility in Algal Endosymbioses Shapes Growth in Reef Corals. Science (80- ) 304:1492-1494

Loram JE, Boonham N, O'Toole P, Trapido-Rosenthal HG, Douglas AE (2007) Molecular quantification of symbiotic dinoflagellate algae of the genus Symbiodinium. Biol Bull 212:25968

Marshall SM (1932) Notes on oxygen production in coral planulae. Grt Barrier ReefExped Sci Rep $1: 253-258$

McGinley MP, Aschaffenburg MD, Pettay DT, Smith RT, LaJeunesse TC, Warner ME (2012) Symbiodinium spp. in colonies of eastern Pacific Pocillopora spp. are highly stable despite the prevalence of low-abundance background populations. Mar Ecol Prog Ser 462:1-7

Meistertzheim A-L, Calves I, Artigaud S, Friedman CS, Laroche J, Paillard C, Ferec C (2012) High Resolution Melting Analysis for fast and cheap polymorphism screening of marine populations. 
Mieog JC, Van Oppen MJH, Berkelmans R, Stam WT, Olsen JL (2009) Quantification of algal endosymbionts (Symbiodinium) in coral tissue using real-time PCR. Mol Ecol Resour 9:74-82

Mieog JC, van Oppen MJH, Cantin NE, Stam WT, Olsen JL (2007) Real-time PCR reveals a high incidence of Symbiodinium clade D at low levels in four scleractinian corals across the Great Barrier Reef: implications for symbiont shuffling. Coral Reefs 26:449-457

National Oceanic and Atmospheric Administration N (2016) "NOAA Declares Third Ever Global Coral Bleaching Event.” Oct. 2015. Web. 12 Jan. 2016.

Naue J, Hansmann T, Schmidt U (2014) High-resolution melting of 12S rRNA and cytochrome b DNA sequences for discrimination of species within distinct European animal families. PLoS One 9:e115575

Pfaffl MW (2001) A new mathematical model for relative quantification in real-time RT-PCR. Nucleic Acids Res 29:2003-2007

Pettay, D. T., and Lajeunesse, T. C. (2013). Long-range dispersal and high-latitude environments influence the population structure of a "stress-tolerant" dinoflagellate endosymbiont. PLoS One 8:e79208.

Pochon X, Gates RD (2010) A new Symbiodinium clade (Dinophyceae) from soritid foraminifera in Hawai'i. Mol Phylogenet Evol 56:492-497

Pochon X, Putnam HM, Gates RD (2014) Multi-gene analysis of Symbiodinium dinoflagellates: a perspective on rarity, symbiosis, and evolution. PeerJ 2:e394

Putnam HM, Stat M, Pochon X, Gates RD (2012) Endosymbiotic flexibility associates with environmental sensitivity in scleractinian corals. Proc R Soc B Biol 279:4352-4361

Quigley KM, Davies SW, Kenkel CD, Willis BL, Matz M V., Bay LK (2014) Deep-sequencing method for quantifying background abundances of Symbiodinium types: Exploring the rare Symbiodinium biosphere in reef-building corals. PLoS One 9(4): e94297

Reaka-Kudla ML (1997) The global biodiversity of coral reefs: a comparison with rain forests. In: (ed) R.-K. et al. (eds) Biodiversity II: Understanding and Protecting our biological resources. National Academy Press, Joseph Henry Press, pp 83-108

Rouzé H, Lecellier G, Saulnier D, Berteaux-Lecellier V (2016) Symbiodinium clades A and D differentially predispose Acropora cytherea to disease and Vibrio spp. colonization. Ecol Evol 6:560-572

Rouzé H, Lecellier GJ, Saulnier D, Planes S, Gueguen Y, Wirshing HH, Berteaux-Lecellier V (2017) An updated assessment of Symbiodinium spp. that associate with common scleractinian corals from Moorea (French Polynesia) reveals high diversity among background symbionts and a novel finding of clade B. PeerJ 5:e2856

Rowan R (2004) Coral Bleaching:Thermal adaptation in reef coral symbionts. Nature 430:742

Rowan R, Knowlton N (1995) Intraspecific diversity and ecological zonation in coral-algal symbiosis. Proc Natl Acad Sci 92:2850-2853

Rowan R, Knowlton N, Baker A, Jara J (1997) Landscape ecology of algal symbionts creates variation in episodes of coral bleaching. Nature 388:265-269

Santos SR, Coffroth MA (2003) Molecular genetic evidence that dinoflagellates belonging to the genus Symbiodinium Freudenthal are haploid. Biol Bull 204:10-20 
Silverstein RN, Correa AMS, Baker AC (2012) Specificity is rarely absolute in coral-algal symbiosis: implications for coral response to climate change. Proc R Soc B Biol Sci 279:2609-2618

Spalding M, Ravilious C, Green E (2001) World Atlas of Coral Reefs. University of California Press and UNEP/WCMC, Berkeley, CA

Spalding MD, Grenfell AM (1997) New estimates of global and regional coral reef areas. Coral Reefs $16: 225-230$

Stat M, Baker AC, Bourne DG, Correa AMS, Forsman Z, Huggett MJ, Pochon X, Skillings D, Toonen RJ, van Oppen MJH, Gates RD (2012) Molecular Delineation of Species in the Coral Holobiont. Adv Mar Biol 63:1-65

Stat M, Carter D, Hoegh-Guldberg O (2006) The evolutionary history of Symbiodinium and scleractinian hosts--Symbiosis, diversity, and the effect of climate change. Perspect Plant Ecol Evol Syst 8:23-43

Stat M, Gates RD (2011) Clade D Symbiodinium in Scleractinian Corals: A "Nugget" of Hope, a Selfish Opportunist, an Ominous Sign, or All of the Above? J Mar Biol 2011:1-9

Stat M, Morris E, Gates RD (2008) Functional diversity in coral-dinoflagellate symbiosis. PNAS 105:9256

Suggett DJ, Goyen S, Evenhuis C, Szabó M, Pettay DT, Warner ME, Ralph PJ (2015) Functional diversity of photobiological traits within the genus Symbiodinium appears to be governed by the interaction of cell size with cladal designation. New Phytol 208:370-381

Tamura K, Stecher G, Peterson D, Filipski A, Kumar S (2013) MEGA6: Molecular Evolutionary Genetics Analysis Version 6.0. Mol Biol Evol 30:2725-2729

Thomas L, Kendrick GA, Kennington WJ, Richards ZT, Stat M (2014) Exploring Symbiodinium diversity and host specificity in Acropora corals from geographical extremes of Western Australia with 454 amplicon pyrosequencing. Mol Ecol 23:3113-26

Thornhill DJ, LaJeunesse TC, Kemp DW, Fitt WK, Schmidt GW (2006) Multi-year, seasonal genotypic surveys of coral-algal symbioses reveal prevalent stability or post-bleaching reversion. Mar Biol 148:711-722

Thornhill DJ, Xiang Y, Fitt WK, Santos SR (2009) Reef endemism, host specificity and temporal stability in populations of symbiotic dinoflagellates from two ecologically dominant Caribbean corals. PLoS One 4:e6262

Thornhill, D. J., Howells, E. J., Wham, D. C., Steury, T. D., and Santos, S. R. (2017). Population genetics of reef coral endosymbionts (Symbiodinium, Dinophyceae). Mol. Ecol. 26, 2640-2659

Tonk L, Sampayo EM, LaJeunesse TC, Schrameyer V, Hoegh-Guldberg O (2014) Symbiodinium (Dinophyceae) diversity in reef-invertebrates along an offshore to inshore reef gradient near Lizard Island, Great Barrier Reef. J Phycol 50:552-563

Ulstrup KE, Van Oppen MJH (2003) Geographic and habitat partitioning of genetically distinct zooxanthellae (Symbiodinium) in Acropora corals on the Great Barrier Reef. Mol Ecol 12:34773484

Ulstrup KE, Van Oppen MJH, Kühl M, Ralph PJ (2007) Inter-polyp genetic and physiological characterisation of Symbiodinium in an Acropora valida colony. Mar Biol 153:225-234

Wangpraseurt D, Pernice M, Guagliardo P, Kilburn MR, Clode PL, Polerecky L, Kuhl M (2015) Light microenvironment and single-cell gradients of carbon fixation in tissues of symbiont-bearing 
corals. ISME J 10:788-792

759

Wangpraseurt D, Polerecky L, Larkum AWD, Ralph PJ, Nielsen DA, Pernice M, Kühl M (2014) The in situ light microenvironment of corals. Limnol Oceanogr 59:917-926

Wilkinson C (2000) Status of Coral Reefs of the World 2000. Australian Institute of Marine Science, Townsville, Australia, 557pp

Wittwer CT, Reed GH, Gundry CN, Vandersteen JG, Pryor RJ (2003) High-Resolution Genotyping by Amplicon Melting Analysis Using LCGreen. Clin Chem 49:853-860

Yuan JS, Reed A, Chen F, Stewart Jr. CN, Stewart Jr CN (2006) Statistical analysis of real-time PCR data. BMC Bioinformatics 7:85-97 


\section{Author contribution}

A.L.M., and L.H. designed research; A.L.M. performed research; A.L.M. and X.P. analyzed data; A.L.M. and X.P. wrote the paper; and J.F.G., S.A.W. and L.H. revised the paper.

\section{Additional Information}

The authors declare no conflict of interest.

\section{Figure legend}

Figure S1 Alignment of 5.8S rDNA partial sequences corresponding to the nine existing Symbiodiniaceae clades extracted from Pochon et al., (2014) used for HRM-primer set design.

Figure S2 Linear regressions derived from DNAs extracted from $1 \times 10^{3}$ to $3 \times 10^{6}$ Symbiodiniaceae cells per extraction (A), and for 2 to 400 cells per extraction of Acropora pulchra embryos (B).

Figure 1 Sampling locations and the host sampling strategy used to investigate the fine-scale assemblage of Symbiodiniaceae phylogenetic clades in different colonies of Acropora pulchra from: (A) Moorea Island (French Polynesia, South-Pacific), and (B) at the two sampling sites of Mahana and Teavaro. Acropora pulchra type colony at Mahana (C), and (D) the pictorial description of the design used to sample the normal $(\mathrm{N})$ and slightly bleached $(\mathrm{sB})$ fragments of colonies.

Figure 2 Linear section of the standard curves obtained for the quantification of Symbiodiniaceae cells using the clade-specific (blue) and genus-generalist Symbiodiniaceae primers (green) for a range of $1 \times 10^{3}$ to $3 \times 10^{6}$ cells (A). Standard curve obtained for the quantification of host cells corresponding to a range of 2 to 400 Acropora pulchra cells (B).

Figure 3 Melt curves and root-mean square error (RMSE) values for the Symbiodiniaceae clade-specific qPCR-High Resolution Melt (HRM) assay. (a) Normalized HRM results using the 5.8S rRNA gene and DNA samples belonging to Symbiodiniaceae clades A to I. (b) Melting peaks derived from the normalized HRM curves presented in A. $(c)$ Mean RMSE value $( \pm \mathrm{SD})$ for the pairwise comparisons of 
793 normalized HRM curves between clades presented in a). Dotted line represented the mean RMSE value 794 obtained for pairwise comparisons within clades.

795 Figure 4 Melting peaks using the 5.8S rRNA gene from mixtures observed in samples (solid line) and 796 in vitro mixtures (dotted line) combining two clades $(a)$ or three clades $(b)$, and clade $\mathrm{A}$ and $\mathrm{D}$ at different 797 proportions $(c)$. Reference melting curves of each clade are shown in grey.

798 Figure 5 Cellular proportions of specific Symbiodiniaceae clades per total DNA (Symbiodiniaceae + 799 host) measured via qPCR- High Resolution Melt for both normal (N) and slightly bleached (sB) 800 fragments of Acropora pulchra colonies sampled at the Mahana and Teavaro sites.

801 Figure 6 Means proportions and standard deviations (SD) of specific Symbiodiniaceae clades per total 802 DNA (Symbiodiniaceae + host) for normal (N) and slightly bleached (sB) fragments of Acropora 803 pulchra colonies sampled at the Mahana and Teavaro sites. *significant differences at $\mathrm{p}<0.05$, $804 * *$ significant differences at $\mathrm{p}<0.01, * * *$ significant differences at $\mathrm{p}<0.001$.

806 Table 1. Combinations of forward and reverse primers used in real-time PCR and High 807 Resolution Melting analyses. 

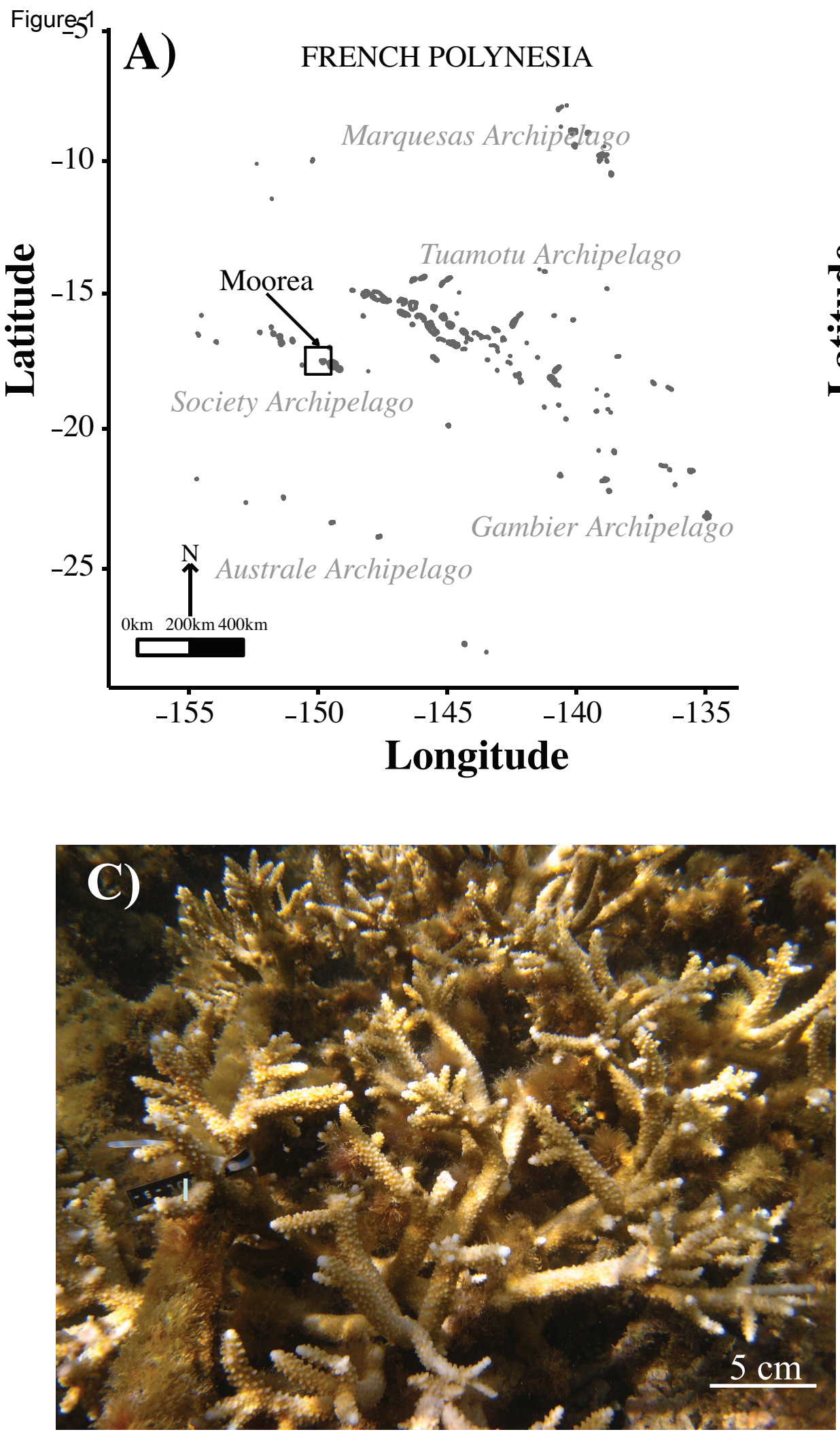

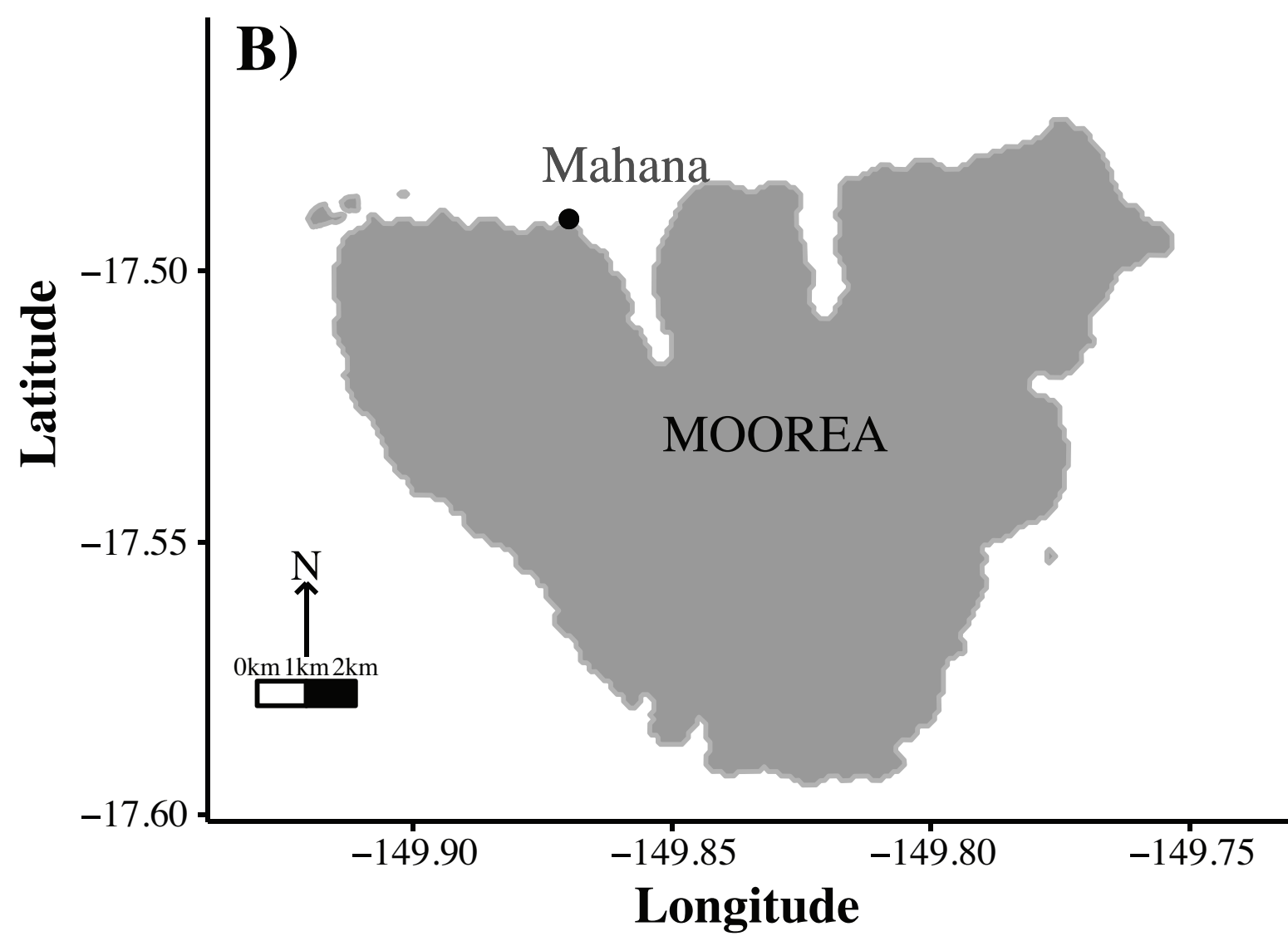

D)

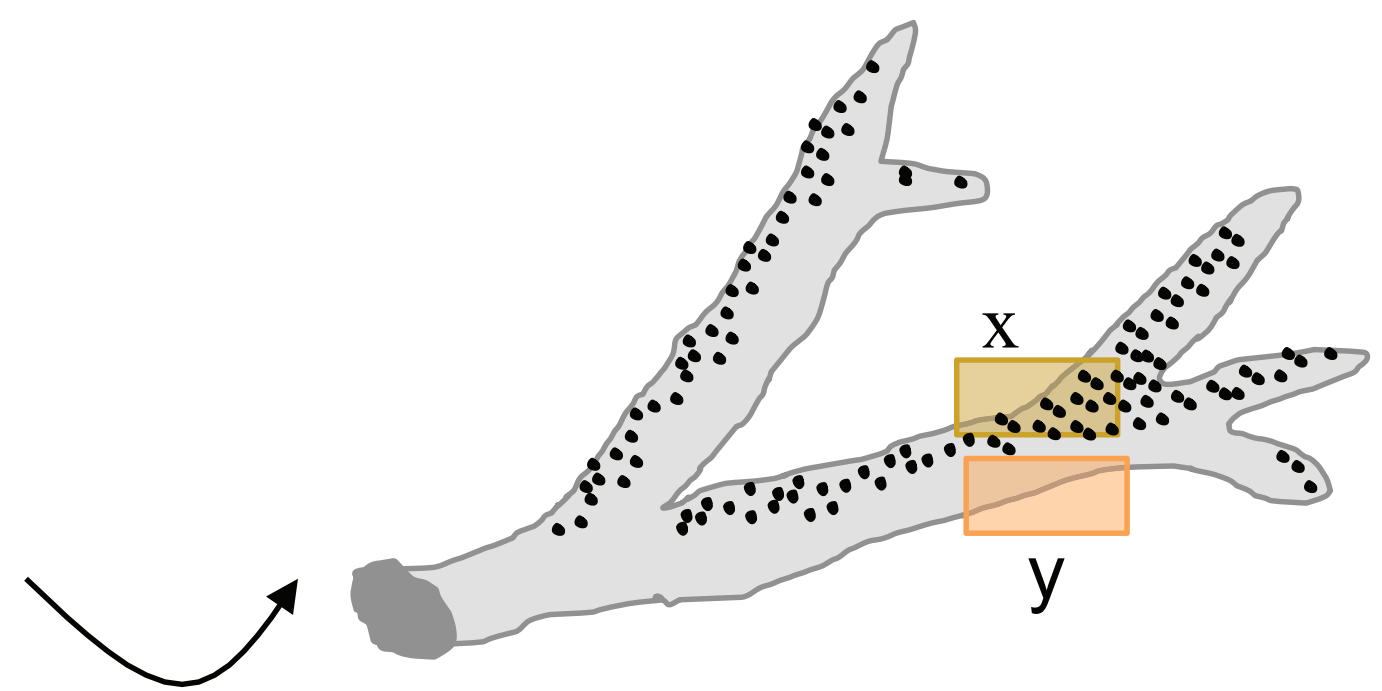



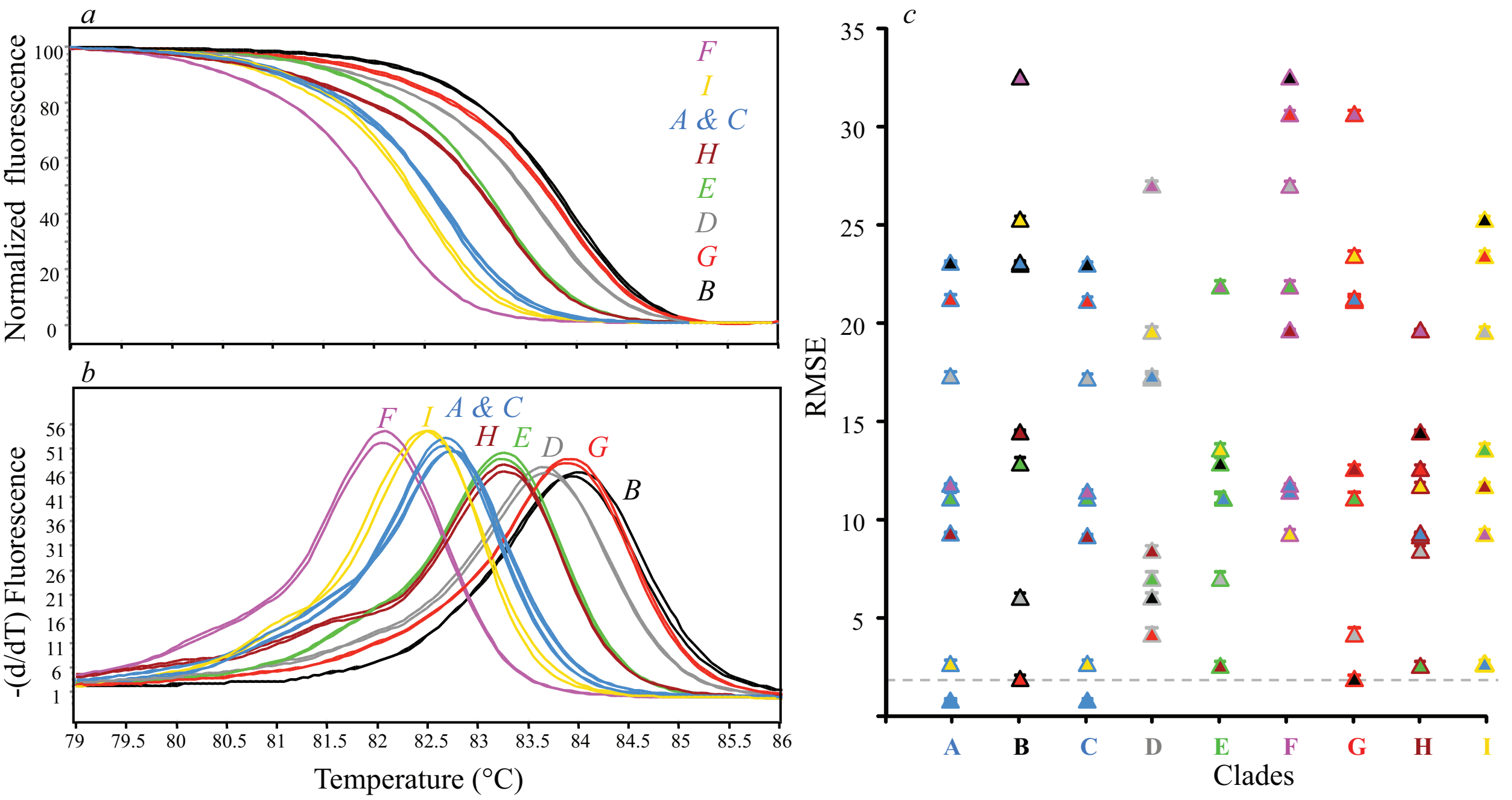

$\triangle A \& C$

$\Delta B$

$\triangle D$

$\Delta E$

$\Delta F$

- $G$

$\Delta H$

$\Delta I$

$\frac{1}{2}$ 

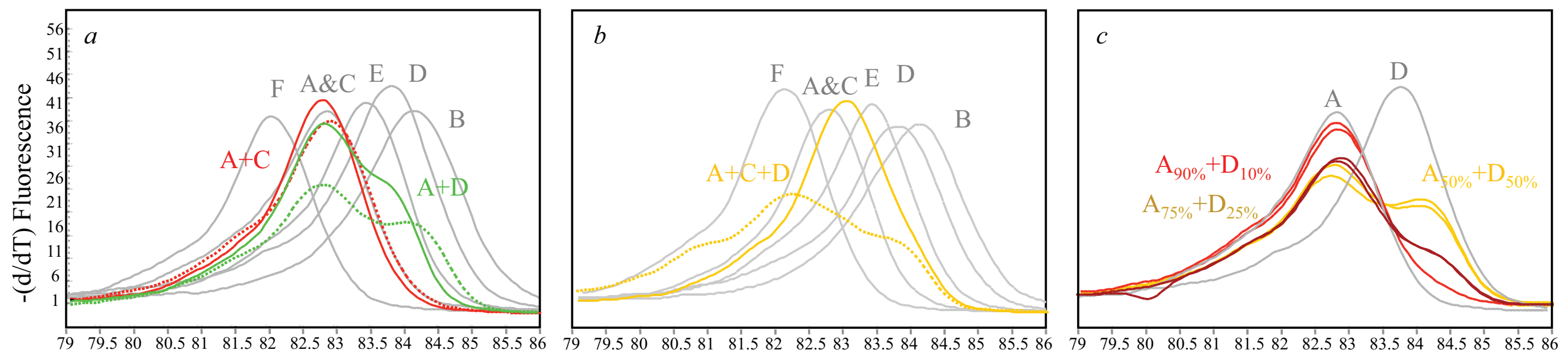

Temperature $\left({ }^{\circ} \mathrm{C}\right)$ 


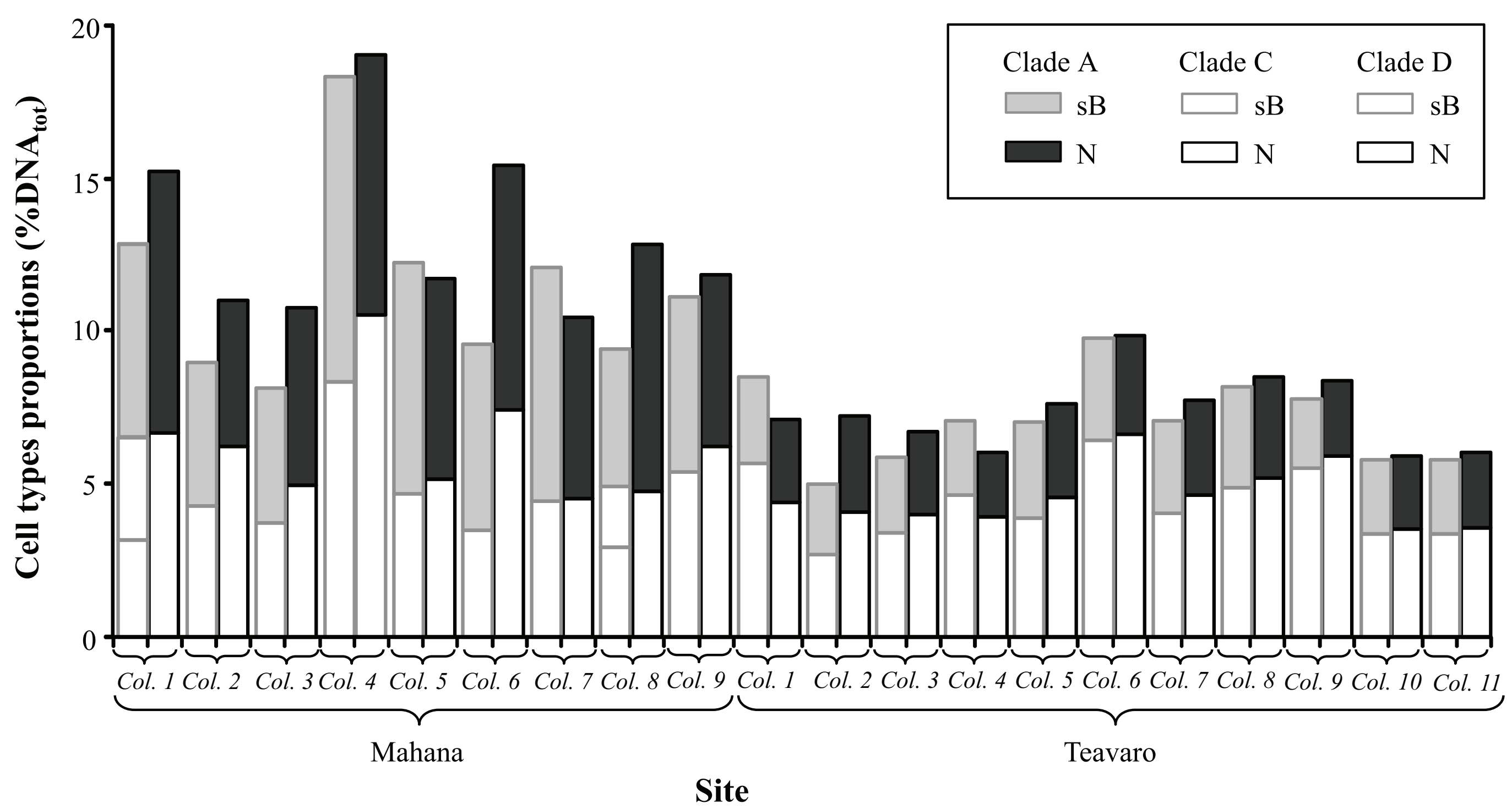


Table 1. Combinations of forward and reverse primers used in real-time PCR and High Resolution Melting analyses.

\begin{tabular}{|c|c|c|c|c|c|c|c|}
\hline Specificity & $\begin{array}{l}\text { Target } \\
\text { gene }\end{array}$ & $\begin{array}{l}\text { Primer Names Forward / } \\
\text { Reverse }\end{array}$ & Forward (5'-3') & Reverse (5'-3') & $\begin{array}{l}\begin{array}{l}\text { Amplicon } \\
\text { size (bp) }\end{array} \\
\end{array}$ & Efficiency & Reference \\
\hline \multicolumn{8}{|l|}{ Symbiont } \\
\hline Symbiodiniacea & $5.8 \mathrm{~S}$ & $\begin{array}{l}\text { SYM_VAR_5.8S2 / } \\
\text { Symb_R }\end{array}$ & GAATTGCAGAACTCCGTGAACC & AGCACTGAAGCAGACATACTCTCAG & 80 & 2 & $\begin{array}{l}\text { Hume et al. (2015) / } \\
\text { This study }\end{array}$ \\
\hline Clade A & ITS2 & Aits2_F / Aits2_R & AGCAGTGCTGCTGCATGCT & TGTCTGACTTCATGCTAGGAAGTGTT & 148 & 1,93 & This study \\
\hline Clade B & ITS2 & Bits2_F / Bits2_F & TTCCAACAAGTCATCGATCGC & TGGCGCATGGGCCA & 65 & 1,88 & This study \\
\hline Clade C & Actin & Cact_F / Cact_R & CCAGGTGCGATGTCGATATTC & TGGTCATTCGCTCACCAATG & 96 & 2,02 & $\begin{array}{l}\text { Cunning and Baker } \\
\text { (2012) }\end{array}$ \\
\hline Clade D & Actin & Dact_F / Dact_R & GGCATGGGGTAAGCACTTCTT & GATCCTTGAACTAGCCTTGGAAAC & 106 & 1,96 & $\begin{array}{l}\text { Cunning and Baker } \\
\text { (2012) }\end{array}$ \\
\hline Clade E & ITS2 & Eits2_F / Eits2_R & TTCCTGGAGAAGCCTTGAG & AGCTTACCTCCCGGTTTGTGTT & 83 & 1,84 & This study \\
\hline Clade F & ITS2 & Fits2_F / Fits2_R & GCCCCTGTGAGCCATTGA & AAGGTGGAATCTTGAATAGAAGCG & 91 & 1,85 & This study \\
\hline Clade G & ITS2 & Gits2_F / Gits2_R & GCCTCGGCGTGTTGTTG & AGCACGTGCATGCTTGCA & 72 & 2 & This study \\
\hline Clade H & ITS2 & Hits2_F / Hits2_R & CCTGCTTTTTGCGTTCCTATG & ACTCAAGCAAAGCCGTGCA & 122 & 2 & This study \\
\hline Clade I & ITS2 & Iits2_F / Iits2_R & ACTCCTGCAAGCCATCGCT & TTGCTATGAATCACAAAGCGCT & 90 & 2 & This study \\
\hline \multicolumn{8}{|l|}{ Host } \\
\hline Acropora pulchra & Actin & Actin_F / Actin_R & ATCATGAAGTGCGATGTGGACA & CTGCATTCTGTCAGCGATTCC & 99 & 2,01 & This study \\
\hline Acropora pulchra & $5.8 \mathrm{~S}$ & 5.8S_F / 5.8S_R & CCGGTGGATCTCTTGGCTC & CGCCATTTGCGTTCAAAGA & 107 & 1,99 & This study \\
\hline
\end{tabular}


Click here to access/download

Electronic Supplementary Material (Tables, Figures, Video, Movie, Audio, etc.) Supplemental data.pdf 